Опыт и перспективы информационного обучения медицинских работников

\author{
г. Томска в Центре IATP научно-медицинской библиотеки Сибирского \\ государственного медицинского университета \\ Захарова Г.В., Молодцова Н.В.
}

\title{
Experience and prospects in medical personnel informational training in IATP Center of SSMU scientific medical library in Tomsk
} Zakharova G.V., Molodtsova N.V.

Научно-медицинская библиотека Сибирского государственного медицинского университета, г. Томск

( ) Захарова Г.В., Молодцова Н.В.

\begin{abstract}
Обучение пользователей в научно-медицинской библиотеке СибГМУ проводится на базе Центра открытого доступа к Интернет, созданного при поддержке американской некоммерческой корпорации «Project Harmony, Ink.». Разработаны обучающие программы, проводятся тематические семинары, курсы, тренинги. В образовательном процессе принимают участие выпускники обменных программ. Система организации обучения пользователей-медиков способствует использованию ресурсов Интернет как источника медицинской и правовой информации.
\end{abstract}

Ключевые слова: библиотека, информационное обслуживание в медицине, компьютерная грамотность.

Training of users in SSMU scientific medical library is made on the basis of Internet Public Center that has been opened under the support of non-profit American corporation - "Project Harmony, Ink". The teaching programs have been developed, subject seminars, courses and trainings are conducted. Graduates of change programs take part in the teaching process. The system of medical users training organization promotes the use of Internet resources as a source of medical and lawful information.

Key words: library, informational service in medicine, computer literacy.

УДК 378:621.3.87.9

В январе 2001 г. при поддержке американской корпорации «Project Harmony» на базе научномедицинской библиотеки Сибирского государственного медицинского университета был открыт Центр открытого доступа к Интернет в рамках Программы «Обучение и доступ к Интернет» (IATP) Управления образовательных и культурных программ Государственного департамента США. Открытие Центра способствовало созданию условий для повышения образовательного и профессионального уровня пользователей библиотеки.
Библиотека взяла на себя новую социальную функцию - обучение пользователей современным информационным технологиям.

Необходимость создания постоянно действующей системы обучения пользователей медицинской библиотеки СибГМУ способствовала организации отдела образовательных программ.

Приоритетными направлениями деятельности библиотеки сегодня являются разработка обучающих программ, проведение образовательных курсов, семинаров, тренингов, занятий для специалистов медицинской науки и практики. 


\section{Научная медицинская информация}

Пользователи могут пройти обучение по следующим программам:

1. Основные навыки работы в текстовом редакторе Microsoft Word.

2. Введение в Интернет.

3. Стратегия поиска научно-медицинской информации в локальных базах данных и в Интернет.

4. Ключевые биомедицинские базы данных в Интернет.

5. Медицинские ресурсы Интернет.

6. Программно-технические средства ввода информации в Интернет.

7. Методология разработки web-pесурсов.

В рамках Программы IATP в 2001-2002 гг. были проведены образовательные курсы «Интернет-технологии В медицинском образовании», «Поиск научно-медицинской информации в Интернет», «Информационные технологии для работников практического здравоохранения». Структура курсов включала лекции, практические занятия, семинары, ролевые игры, индивидуальные консультации, анкетирование.

Программа образовательного курса «Интернет-технологии в медицинском образовании» состояла из разделов и тем, направленных на ознакомление сотрудников СибГМУ и выпускников обменных программ ЕСА с принципами организации глобальной сети Интернет, программнотехническими средствами работы в Интернет, методологией разработки web-ресурсов. По окончании курса слушатели представили дипломную работу в виде собственного webресурса.

Образовательный курс «Поиск научномедицинской информации в Интернет» был организован для руководителей компьютерных классов, кафедр СибГМУ, учреждений практического здравоохранения, медицинских НИИ ТНЦ СО РАMН и медицинских библиотек г. Томска. Ориентация на специализированные группы была обусловлена тем, что в дальнейшем слушатели будут выступать в качестве консультантов для пользователей-медиков. Слушатели были обучены рациональному и оперативному алгоритму поиска научно-медицинской информации в Интернет с целью повышения качества обслуживания пользо-

вателей-медиков и дальнейшего внедрения современных технологий в медицинское образование, науку и практику.

В рамках образовательного курса «Информационные технологии для работников практического здравоохранения», В организации которого принимал участие выпускник обменных программ, главный врач городской больницы <3 г. Томска А.А. Орешин, прошли обучение медицинские работники лечебных учреждений города. Слушатели приобрели навыки работы на ПК и в Интернет, что способствовало повышению их профессиональной компетентности.

В библиотеке ежемесячно проводятся тематические семинары как для общей группы пользователей, так и для специализированных групп слушателей, например, для врачей и медицинских сестер лечебно-профилактических учреждений, первокурсников или аспирантов СибГМУ, сотрудников медицинских библиотек. В центре IATP прошли семинары по медицинским ресурсам Интернет для анестезиологов, кардиологов, гастроэнтерологов, пульмонологов, рентгенологов, иммунологов, генетиков.

Центр IATP работает в тесном контакте с сотрудниками кафедр СибГМУ и других вузов города, которые выступают в качестве тренеров.

Медики-выпускники обменных программ также активно привлекаются к проведению тематических семинаров. Выпускником программы «Акт в поддержку свободы» С.А. Михеевым были организованы тематические семинары «ИнтернетУлыбка» для пациентов “Операции "Улыбка"», семинары по правовой и патентной информации регулярно проводит выпускник программы «Открытый мир» Л.В. Захарова, «Поиск грантов и благотворительных фондов в Интернет» проводит выпускник программы «Актуальные вопросы современности» А.Н. Арефььева.

Темы семинаров определяются на основе анкетирования и пожеланий пользователей и представлены по следующим направлениям:

1. Современные информационные технологии в высшем медицинском образовании.

2. Медицинские ресурсы Интернет. 


\section{Вести из библиотеки}

3. Ресурсы Интернет по общественным и гуманитарным наукам.

4. Использование информационных технологий в медицинской библиотеке.

5. Программы международных обменов. Гранты и благотворительные фонды.

6. Мультимедийные образовательные ресурсы.

7. Интернет как средство профессиональной коммуникации.

Календарный план проведения тематических семинаров составляется на год, доступен для широкой аудитории и представлен на сайте Центра IATP (http://study.tomsk.ru).

За период работы Центра IATP в научномедицинской библиотеке СибГМУ было проведено 910 часов занятий и обучено 2400 пользователей.

Система организации обучения медиков в Центре IATP способствует использованию ресурсов Интернет как источника медицинской и правовой информации для принятия правильных решений в клинической практике, науке и образовании, развитию профессиональной коммуникации для обмена информацией с коллегами из отдаленных регионов страны и зарубежья.

В дальнейшей работе Центра IATP планирует расширение круга потенциальных пользователей из новых научно-исследовательских институтов ТНЦ СО РАМН (НИИ гастроэнтерологии, НИИ акушерства, гинекологии и перинатологии) и факультета клинической психологии и психотерапии СибГМУ, сотрудничество с Центром довузовской подготовки и Центром последипломной подготовки СибГМУ.

В планах Центра также обучение медицинского персонала районных больниц, возможна организация выездных обучающих мероприятий в лечебно-профилактические учреждения области.

В сотрудничестве с редакционноиздательским отделом медицинского университета будет продолжаться работа над выпуском методических пособий по основным темам семинаров.

С целью привлечения выпускников обменных программ к образовательной деятельности Цен- тра ІАТР ведется работа по организации клуба выпускников-медиков.

\section{Новые поступления}

\section{в научно-медицинскую библио- теку \\ Сибирского государственного медицинского университета}

\section{Новая коллекция книг}

Значительным событием для научномедицинской библиотеки СибГМУ стала передача в ее фонды книг из личной библиотеки профессора Ю.И. Красильникова.

Юрий Иннокентьевич Красильников, доктор медицинских наук, профессор, действительный член Академии медико-технических наук РФ, член правления Российского общества оториноларингологов, член редакционного совета журнала «Вестник оториноларингологии» и межведомственного научного совета, подарил библиотеке СибГМУ 350 книг из своей личной коллекции. Особую ценность представляют раритетные издания, вышедшие в свет до 1940 г. Некоторые из них в свое время принадлежали главе томской врачебной династии ФетисовыхКрасильниковых профессору Александру Георгиевичу Фетисову (1896-1979). Долгий трудовой и творческий путь прошел старейший томский ученый. Заведование кафедрой оториноларингологии он совмещал с руководством в масштабах факультета и института, был деканом лечебного факультета и проректором по учебной работе, был участником практически всех всесоюзных и всероссийских съездов и конференций по оториноларингологии. Старинные книги имеют экслибрисы Фетисова, а также рукописные отметки, сделанные в начале XX в. Среди книг: «Сборник научных трудов», посвященный проф. Л.Т. Левину (Л.: 1925); несколько экземпляров сборника «Русская отоларингология» под ред. Л.Т. Левина (Л.: 1928); несколько томов «Архива советской оториноларингологии» (Л.: ОГИЗ, 1936-1937 гг.). В коллекции есть книги, помеченные еще и экслибрисом основателя первой в Сибири кафедры оториноларингологии Томского 
университета, известного ученого А.М. Никольского (1878-1933).

Книги, имеющие экслибрисы и пометки трех знаменитых ученых, внесших большой вклад в развитие медицины, - это очень ценные издания для отдела редких книг библиотеки.

Большую часть переданных в фонд библиотеки книг составляют труды по вопросам оториноларингологии различных научно-исследовательских институтов.

Научно-медицинская библиотека выражает огромную благодарность профессору Ю.И. Красильникову за ценные подарки. Книги будут храниться с пометкой «Дар Ю.И. Красильникова».

\section{Новые журналы}

врачей, юристов, специалистов в области медицинского страхования - всех тех, кто испытывает недостаток в медико-правовой информации. Проект осуществлен под эгидой Национальной ассоциации медицинского права. Главный редактор журнала - заслуженный юрист России, д-р мед. наук, проф. Ю.Д. Сергеев // Медицинское право. 2003. 1.

\section{Новый CD-ROM}

В 2003 г. в библиотеке появилась коллекция мультимедийных компакт-дисков компании «Кирилл и Мефодий». Данная компания специализируется на выпуске обучающих и развивающих энциклопедий. На данный момент в библиотеке имеются CD-ROMы:

- «5555 шедевров мировой живописи»,

- «Антология русской культуры от Нестора до Булгакова»,

- «Большая энциклопедия»,

- «Московские прогулки»,

- «Современное российское искусство»,

- «Туристический атлас мира»,

- «Шедевры архитектуры»,

- «Шедевры музыки»,

- «Шедевры русской живописи»,

- «Энциклопедия кино»,

- «Энциклопедия коллекционера»,

- «Энциклопедия этикета».
«Биомедицинская химия». Журнал знакомит читателей с обзорными статьями по наиболее актуальным проблемам биологии и медицины, результатами экспериментальных и клинических исследований. Планируется появление таких разделов как энзимология, протеомика, геномика, биоинформатика, клеточная сигнализация. Учредитель журнала - Президиум Российской академии медицинских наук, главный редактор А.И. Арчаков // Биомедицинская химия. 2003. $<1$.

«Медицинское право» - федеральный научно-практический журнал, освещающий актуальные проблемы медицинского права, деонтологии и биоэтики, вопросы медицинского страхования.

Предназначен

для

В дальнейшем мы будем более подробно освещать каждый из этих мультимедийных проектов.

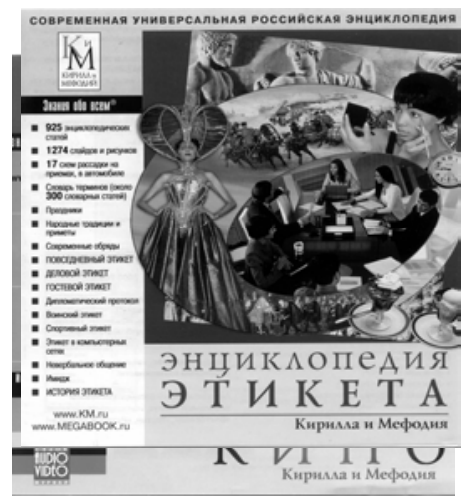

«Энциклопедия этикета Кирилла и Мефоодия» - адаптированная для библиотек версия энциклопедии от известной мультимедийной компании, призванная улучшить знания о тонкостях общения, культуры принятия пищи и других не менее важных сторон повседневной человеческой жизни. Помимо статей, в энциклопедии присутствует 


\section{Вести из библиотеки}

словарь, содержащий расшифровку основных понятий этикета, терминов из области культуры, названий экзотических блюд. Статьи и словарь сопровождаются иллюстрациями.

«Энциклопедия кино Кирилла и Мефоодия» адаптированная для библиотек версия энциклопедии содержит в себе подробнейшую информацию об истории развития кинематографа, о наиболее известных лентах, о режиссерах с мировым именем, о лидерах кассового проката. В энциклопедии присутствует удобная система поиска информации, позволяющая находить нужный материал по тематике, по ключевым словам, по оставленным ранее закладкам. Наличие приложения с музыкальными фрагментами, а также кадрами из фильмов, безусловно, повышает общую привлекательность этой энциклопедии.

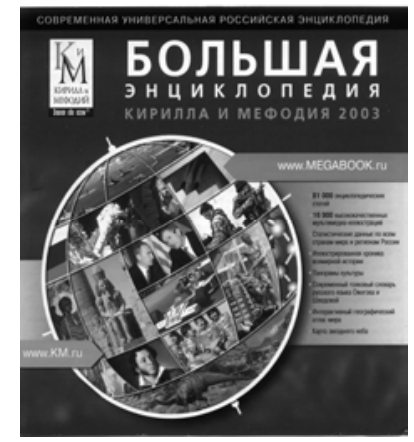

«Большая энциклопедия Кирилла и Мефодия» - еще одна адаптированная для библиотек энциклопедия является сборником статей, посвященных самым разным явлениям человеческой жизни. Помимо удобной системы поиска информации, в энциклопедии присутствует чрезвычайно богатое приложение. Здесь и карта звездного неба, и атлас Земли, и анимированная история цивилизации, и подбор точных статистических данных по самым различным тематикам, начиная от ВНП России до уровня рождаемости в Томске. Также в энциклопедии имеется сборник основных юридических документов РФ, а также словарь иностранных слов, словарь Ожегова и многое другое. 


\section{ТРУДЫ СИБИРСКИХ УЧЕНЫХ-МЕДИКОВ}

Актуальные вопросы медицинского обеспечения войск, подготовки и усовершенствования военно-медицинских кадров: Материалы научно-практической конференции / Под ред. О.А. Жаткина. Томск, 2003. 278 с.

Редактор:

Жаткин О.А. - д-р мед. наук, проф. кафедры организации и тактики медицинской службы, начальник Томского военно-медицинского института (г. Томск), генерал-майор медицинской службы.

В сборнике представлены материалы научнопрактической конфреренции профессорскопреподавательского состава Томского военномедицинского института, касающиеся современного состояния медицинского обеспечения войск, подготовки и усовершенствования медицинских кадров, актуальных проблем медикобиологических и клинических исследований в области терапии, хирургии, фармации.

Для преподавателей, научных работников, практических врачей и провизоров, курсантов и слушателей военно-медицинских вузов.

Клиническая нейроиммунопсихология I В.Я. Семке, Т.П. Ветлугина, Т.И. Невидимова и др. Томск, 2003. 300 c.

Авторы:

Семке В.Я. - академик РАМН, д-р мед. наук, проф., директор НИИ психического здоровья ТНЦ CO PAMH (г. Томск).

Ветлугина Т.П. - д-р мед. наук, проф., руководитель отдела биологической психиатрии, руководитель лаборатории клинической психонейроиммунологии НИИ психического здоровья ТНЦ CO PAMH (г. Томск).

В монографрии рассматриваются методологические принципы клинической нейропсихоиммунологии как отдельного научного направления. Обобщены материалы многолетних исследований по проблеме психонейроиммуномодуляции в клинике и терапии основных психических расстройств (шизофрении, пограничных, афффектив- ных и аддиктивных) с позиций клиниконозологических и клинико-динамических критериев их диагностики. Представлены технологические основы методов терапии и реабилитации в клинической психонейроиммунологии.

Для специалистов, работающих в области психиатрии, иммунологии и психонейроиммунологии.

Надэпитальный слизистый слой желудочно-кишечного тракта и его функциональное значение I Н.А. Кривова, Г.Ц. Дамбаев, В.Е. Хитреев. Томск, 2002. 316 с.

Авторы:

Дамбаев Г.Ц. - чл.-кор. РАМН, д-р мед. наук, проф., заведующий кафедрой госпитальной хирургии с курсом хирургии ФУВ СибГМУ (г. Томск).

В монографии подробно рассмотрен состав надэпителиального слизистого слоя желудочнокишечного тракта в норме и при изменении его функционального состояния. На многочисленных экспериментах показаны видовые, возрастные и органные отличия, а также функциональные особенности состава надэпителиального слизистого слоя. С помощью разработанного комплекса методов, изучены процессы биосинтеза, секреции и деградации гликопротеинов, оценен уровень протективных свойств надэпителиального слизистого слоя при моделировании различных хирургических операций на желудочно-кишечном тракте.

Для терапевтов, гастроэнтерологов, врачей общей практики, студентов медицинских вузов.

Назаров И.П., Винник Ю.С., Дунаевская С.С. Иммунопатология в хирургии и анестезиологии. Красноярск, 2003. 297 с.

Авторы:

Назаров И.П. - д-р мед. наук, проф., заведующий кафедрой анестезиологии и реаниматологии ФУВ КрасГМА (г. Красноярск), главный анестезиолог Красноярского края. 
Винник Ю.С. - д-р мед. наук, профр. кафедры общей хирургии КрасГМА (г. Красноярск), заслуженный врач РФ.

Дунаевская С.С. - канд. мед. наук, ассистент кафедры общей хирургии КрасГМА (г. Красноярск).

Монография посвящена одному из важнейших и недостаточно изученных разделов медицины - нарушениям иммунитета и их коррекции у хирургических больных. В первой части работы описаны влияния хирургической травмы и анестезии на иммунитет больных, способы коррекции иммунодефицита. Приводится оригинальная методика стресспротекции ганглиолитиками и адренолитиками как эфффективный способ коррекции иммунитета у взрослых и детей при различных хирургических вмешательствах.

Во второй части авторы останавливаются на патогенезе и интенсивной терапии гнойносептических состояний в хирургии. В третьей части впервые приводятся данные комплексного исследования иммунного статуса с использованием методик, отражающих фрункциональное состояние лимфоцитов, больных различными фрормами острого панкреатита.

В четвертой части работы рассматриваются современные аспекты этиопатогенеза вторичного иммунодефицита и ожогового сепсиса, состояние иммунитета у ожоговых больных и его коррекция.
Для врачей анестезиологов-реаниматологов, хирургов, иммунологов, травматологов.

\section{Разумов В.В. Флюороз как проявление преждевременного старения и атавистическо- го остеогенеза. Томск, 2003. 112 с.}

Автор:

Разумов В.В. - д-р мед. наук, проф., ведущий научный сотрудник отдела медицины труда НИИ КПГПЗ СО РАМН, заведующий кафедрой профпатологии Иркутского ГИДУВа (г. Иркутск).

В монографии по результатам собственных клинических исследований и анализа данных литературы о различных этиологических формах флюороза изложены механизмы патогенности фторидов и новое толкование сущности хронической фртористой интоксикации. С использованием представлений о морфогенетической функции соединительной ткани, стромально-паренхиматозных взаимодействий делается попытка синтетического подхода к оценке фртористых остео- и висцеропатий.

Для ученых и врачей всех терапевтических специальностей.

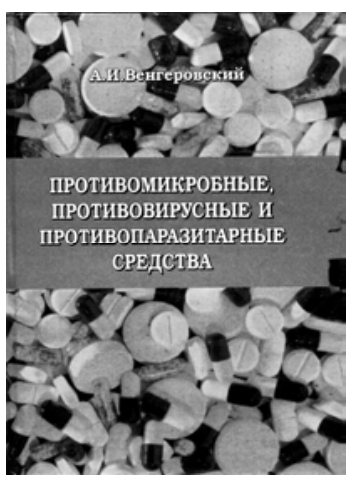

\title{
МИНИСТЕРСТВО ЗДРАВООХРАНЕНИЯ РОССИЙСКОЙ ФЕДЕРАЦИИ СИБИРСКИЙ ГОСУДАРСТВЕННЫЙ МЕДИЦИНСКИЙ УНИВЕРСИТЕТ
}

\section{ПРОТИВОМИКРОБНЫЕ, ПРОТИВОВИРУСНЫЕ И ПРОТИВОПАРАЗИТАРНЫЕ СРЕДСТВА}

\author{
Автор - профрессор СибГМУ
}

\section{А.И. Венгеровский}

Учебное пособие подготовлено профессором СибГМУ (г. Томск)

А.И. Венгеровским.

В данном издании рассмотрены современные проблемы химиотерапии инфекционных заболеваний, а также фрармакодинамика, фрармакокинетика, клиническое применение и токсикология противомикробных, противовирусных, противопаразитарных и противоопухолевых средств. Представлены фундаментальные принципы действия лекарственных средств и клинические подходы к фармакотерапии заболеваний. Особое внимание уделяется проблеме резистентности микроорганизмов к химическим средствам.

Для студентов, врачей и провизоров.

Объем - 432 страницы, твердый переплет, 2002 г.

Стоимость издания - 170 руб. 
Научная медицинская информация

Уважаемые коллеги!

Для того чтобы приобрести учебное пособие «Противомикробные, противовирусные и противопаразитарные средства», вам необходимо:

- заполнить счет с указанием количества экземпляров,

- оплатить необходимое вам количество экземпляров учебника по указанным банковским реквизитам,

- направить нам информацию о вашем заказе любым удобным для вас способом.

Мы будем счастливы выполнить ваш заказ и доставить вам учебное пособие по низкой цене и в самые короткие сроки!

Контактная информация

Почтовый адрес:

Телефоны: (3822) 51-53-15, 51-48-52, 51-57-08 634050, Россия, г. Томск, пр. Ленина, 107,

Факс: (3822) 53-33-09

Научно-медицинская библиотека

E-mail: bulletin@bulletin.tomsk.ru

Сибирского государственного медицинского университета

9. 


\section{НОВОСТИ МЕДИЦИНЫ}

(по материалам российской печати)

\section{Томский препарат - лучший}

Одной из новинок 2002 г., разработанных специалистами Томского НИИ фрармакологии, стал препарат «Импаза».

Он создан на принципе введения в организм сверхмалых доз антител и по своему фрармакологическому действию сходен с известной во всем мире «Виагрой». От импортной «Виагры» у томской «Импазы» только положительные отличия - нулевая токсичность и отсутствие риска каких бы то ни было побочных эфрфектов.

Поступив в прошлом году в широкую продажу, препарат в течение первых же месяцев оправдал все возложенные на него разработчиками и производителями надежды.

- На днях были опубликованы результаты исследования, проведенного именитым московским аналитическим агентством «МДМ», - рассказывает директор НИИ фармакологии Е.Д. Гольдберг. - По данным этого исследования, «Импаза» признана препаратом 2002 г., новинкой, которая в минувшем году стартовала на российском рынке удачнее всех остальных лекарственных средств как отечественного, так и зарубежного производства.

Уже закончены клинические испытания еще одного препарата томских фрармакологов «Экорсина». Создан он на основе экстракта коры осины и призван помогать людям, страдающим язвенной болезнью желудка и двенадцатиперстной кишки. Все документы, необходимые для запуска «Экорсина» в промышленное производство, уже находятся на утверждении в Москве. Определен и будущий производитель - Бийский витаминный завод. Специалисты лаборатории онкофармакологии, которые трудились над этим препаратом, рассчитывают, что его ждет столь же блестящее будущее, как и «Импазу». В эти же дни вышла в свет книга коллектива авторов «Экорсина» во главе с руководителем лаборатории Е.П. Зуевой «Лекарственные растения в терапии язвенной болезни желудка и двенадцатиперстной кишки». В ней обобщается опыт том- ских фрармакологов в обращении к кладовым сибирской природы в борьбе с онкологическими и другими тяжелыми заболеваниями.

\section{Смертность младенцев по-прежнему высока}

В Москве прошло совещание по проблемам охраны материнства и детства. В этой встрече принимали участие вице-президент Российской академии медицинских наук Владимир Кулаков, заместитель министра здравоохранения РФ Ольга Шарапова и главные специалисты - акушерыгинекологи и неонатологи практически всех российских регионов.

Как рассказала по возвращении из столицы Любовь Агаркова, директор НИИ акушерства, гинекологиии и перинатологии Томского научного центра СО РАMН, на совещании обсуждались сразу несколько вопросов. Но одной из самых серьезных по-прежнему остается ситуация с ВИЧинфицированными детьми. Разработан специальный протокол, по которому ведут детей от ВИЧ-инфицированных матерей во время родов и после рождения. Сейчас настал такой момент, когда первые ВИЧ-инфицированные с рождения дети должны пойти в школу. Как быть с ними дальше пока непонятно.

Смертность новорожденных в России остается по-прежнему высокой. Гораздо больше внимания следовало бы, по мнению участников совещания, уделять дородовой диагностике в связи с увеличением в нашей стране наследственных и врожденных заболеваний. Ведь здоровье будущих матерей тоже оставляет желать лучшего.

В России уже действуют несколько федеральных программ: «Артериальная гипертония и беременность», «Перинатальная диагностика и врожденные пороки сердца» и другие, призванные улучшить сложившуюся ситуацию. В эти программы НИИ акушерства, гинекологии и перинатологии будет активно включаться. Помимо всех перечисленных проблем, в Сибири очень остро стоит вопрос с техническим оснащением: не хватает эле- 
ментарного оборудования. К примеру, в томских роддомах нет даже аппаратов с сервовентилятором для искусственной вентиляции легких.

Задача главных специалистов службы охраны материнства и детства - сделать анализ положения дел в российских регионах. Аналитические отчеты рассмотрит замминистра Ольга Шарапова. И вскоре эти же вопросы будут обсуждаться уже на правительственном уровне.

Томский вестник. 2003. 17 июня

\section{Уникальную диагностику по выявле-} нию

\section{вируса болезни Лайма исследуют томские ученые}

В вирусологической лаборатории областного центра Госсанэпиднадзора проходят последние испытания уникальной диагностики по выявлению вируса болезни Лайма, которая позволяет выявить болезнь Лайма на генном уровне, а также обнаружить возбудителя болезни Лайма как в суспензии клеща, так и в крови больных людей. Разработан метод российскими специалистами НТМ - «Наука - техника молодежи».

Новая диагностика - это стопроцентное выявление болезни Лайма. Исследования по диагностике Лайма ведутся на новейшем приборе. Его стоимость - 200 тыс. рублей. Ранее прибор использовали только при диагностике гепатита и ВИЧ-инфекции. Н. Зинченко, главный санитарный врач ЦГСЭН Томской области, отметил: «Постановка диагноза возложена на нас, у нас единственная вирусологическая лаборатория, а если этот метод будет введен, то любая клиника сможет приобрести эту диагностику». В ближайшее время выявлять болезнь по новому методу будут у жителей Томской области.

http://www.atf.tsu.ru/

\section{Операция в прямом эфире}

21 мая на базе Томского НИИ кардиологии состоялся двухдневный международный научнопрактический семинар по теме «Актуальные вопросы лечения врожденных пороков сердца». Организатором семинара, помимо НИИ кардиологии ТНЦ СО РАМН, выступила Европейская ассоциация

сердечно-сосудистой хирургии.

В числе именитых гостей - профессора Пауль Симон и Ульрика Зальцер-Мухар из Вены, главный кардиохирург Сибирского федерального округа, директор Новосибирского НИИ патологии кровообращения проф. А.М. Караськов, директор кемеровского кардиодиспансера, чл.-кор. РАМН, проф. Л.С. Барбараш и другие специалисты из различных городов России. Председательствовал на столь представительном медицинском форуме руководитель отделения сердечнососудистой хирургии Томского кардиоцентра проф. В.М. Шипулин.

В ходе семинара обсуждались новые технологии в хирургии врожденных пороков сердца, технологии производства биоматериалов для кардиохирургии, современная тактика лечения новорожденных с пороками сердца. Помимо докладов, прошла прямая трансляция пятичасовой операции по замене аортального клапана, ведущим хирургом которой выступил австриец Пауль Симон. Подобные операции в России до сих пор проводятся редко.

Красное знамя. 2003. Май

\section{Второе рождение онкополиклиники}

В середине мая состоялось значимое для Томска событие - открытие восстановленной поликлиники областного онкодиспансера.

На торжественную церемонию открытия собрались руководители областного департамента здравоохранения, НИИ онкологии СО РАMН, врачи онкологического диспансера, пациенты. С прибытием губернатора В.М. Кресса и его заместителя по социальным вопросам А.М. Дронникова все переместились в уютное фойе поликлиники, центральную лестницу которого пересекала яркая красная ленточка.

- Это лишь первый шаг на пути общего преобразования томской онкологической службы, подчеркнул в своем выступлении В.М. Кресс. Отстроим новый корпус в районе ОКБ, снабдим онколо-

гов транспортом, чтобы поездки на окраину Том- 


\section{Новости медицины}

ска не мешали работать врачам и не нервировали пациентов. Уже подписано распоряжение о выделении 500 тыс. рублей на приобретение для этой поликлиники новой мебели.

Сообщение губернатора было встречено аплодисментами.

- Радостно за коллег, - сказал директор НИИ онкологии СО РАМН Е.Л. Чойнзонов, - уверен, что теперь работа наших коллективов на благо соотечественников станет еще плодотворHee.

Когда была разрезана красная ленточка, хозяева поликлиники провели гостей по еще пахнущим свежей краской этажам и кабинетам своего нового старого дома. Его открытие - прекрасный и, дай бог, не последний подарок томской онкологической службе, которая в следующем году будет отмечать 80-летний юбилей.

Красное знамя. 2003. 16 мая

\section{КАЛЕНДАРЬ МЕДИЦИНСКИХ КОНФЕРЕНЦИЙ И СЪЕЗДОВ}

\begin{tabular}{|c|c|c|c|}
\hline $\begin{array}{l}\text { Дата } \\
\text { проведе- } \\
\text { ния }\end{array}$ & Мероприятие & $\begin{array}{l}\text { Место } \\
\text { проведе- } \\
\text { ния }\end{array}$ & Контактная информация \\
\hline $\begin{array}{l}\text { Ноябрь } \\
2003 \text { г. }\end{array}$ & $\begin{array}{l}\text { Второй съезд терапевтов Сибири и } \\
\text { Дальнего Востока }\end{array}$ & $\begin{array}{l}\text { Россия, } \\
\text { Новоси- } \\
\text { бирск }\end{array}$ & $\begin{array}{l}\text { 630003, г. Новосибирск, } \\
\text { Владимировский спуск, 2а. } \\
\text { ГУ НИИ терапии СО РАМН. } \\
\text { Тел.: (383-2) 29-32-53, 20-76-46, 29-20- } \\
48, \\
22-55-11 \\
\text { Факс: (383-2) 22-28-21, 29-32-53 }\end{array}$ \\
\hline $\begin{array}{l}\text { Ноябрь } \\
2003 \text { г. }\end{array}$ & $\begin{array}{l}\text { Научно-практическая школа «Внутри- } \\
\text { оперативный лабораторный контроль } \\
\text { качества аналитических измерений» }\end{array}$ & $\begin{array}{l}\text { Россия, } \\
\text { Ангарск }\end{array}$ & Тел./сракс: (395-1) 55-40-77 \\
\hline $\begin{array}{l}\text { Ноябрь } \\
2003 \text { г. }\end{array}$ & $\begin{array}{l}\text { Молодежный академический форум } \\
\text { «Молодежь и наука Сибири» }\end{array}$ & $\begin{array}{l}\text { Россия, } \\
\text { Чита }\end{array}$ & $\begin{array}{l}\text { 672090, г. Чита, ул. Бутина, 26, a/я } 147 . \\
\text { Тел.: (302-2) 21-25-12, 21-17-21 } \\
\text { Факс: (302-2) 21-25-82 } \\
\text { E-mail: poot@cinr.chita.su }\end{array}$ \\
\hline $\begin{array}{l}\text { Ноябрь } \\
2003 \text { г. }\end{array}$ & $\begin{array}{l}\text { Областная научно-практическая кон- } \\
\text { ференция «Скрининг и лечение рака } \\
\text { молочной железы» }\end{array}$ & $\begin{array}{l}\text { Россия, } \\
\text { Магадан }\end{array}$ & $\begin{array}{l}\text { Магаданский облонкодиспансер. } \\
\text { С.Н. Тараканов } \\
\text { Тел.: (413-22) 2-39-40 }\end{array}$ \\
\hline $\begin{array}{l}11-12 \\
\text { ноября } \\
2003 \text { г. }\end{array}$ & $\begin{array}{l}\text { Научно-практическая конференция } \\
\text { «Актуальные проблемы лаборатор- } \\
\text { ной медицины» }\end{array}$ & $\begin{array}{l}\text { Россия, } \\
\text { Томск }\end{array}$ & $\begin{array}{l}634050 \text { г. Томск, Московский тр-т, 2, } \\
\text { СибГМУ. Кафредра фундаментальных ос- } \\
\text { нов клинической медицины. } \\
\text { Зав. каф. профр. Н.В. Рязанцева } \\
\text { Тел.: (382-2) 41-73-80, 41-59-07 } \\
\text { E-mail: ryazan@ @mail.tomsknet.ru } \\
\text { Tехнический секретарь } \\
\text { 634034, г. Томск, пр. Кирова 14a. }\end{array}$ \\
\hline
\end{tabular}


Научная медицинская информация

\begin{tabular}{|c|c|c|c|}
\hline $\begin{array}{l}\text { Дата } \\
\text { проведе- } \\
\text { ния }\end{array}$ & Мероприятие & $\begin{array}{l}\text { Место } \\
\text { проведе- } \\
\text { ния }\end{array}$ & Контактная информация \\
\hline & & & $\begin{array}{l}\text { Томское региональное отделение } \\
\text { (ТРООО РАМЛД), } \\
\text { Е.А. Пигузова } \\
\text { Тел.: (382-2) 281-853, 410-022 } \\
\text { Факс: (382-2) 410-022 } \\
\text { E-mail: santi@mail.tomsknet.ru }\end{array}$ \\
\hline $\begin{array}{l}13-14 \\
\text { ноября } \\
2003 \text { г. }\end{array}$ & $\begin{array}{l}\text { Региональная научно-практическая } \\
\text { конференция «Инфрормационные тех- } \\
\text { нологии в медицине и биотехниче- } \\
\text { ские системы» }\end{array}$ & $\begin{array}{c}\text { Россия, } \\
\text { Томск }\end{array}$ & $\begin{array}{l}\text { 634050, г. Томск, Московский тр-т, 2, } \\
\text { СибГМУ. Кафедра медицинской } \\
\text { и биологической кибернетики. } \\
\text { Зав. кафр. проф. Я.С. Пеккер } \\
\text { Тел.: (382-2) 41-59-24 }\end{array}$ \\
\hline $\begin{array}{c}21 \text { ноября } \\
2003 \text { г. }\end{array}$ & $\begin{array}{l}\text { Областная научно-практическая } \\
\text { конференция «Использование ле- } \\
\text { чебного питания в педиатрической } \\
\text { практике» }\end{array}$ & $\begin{array}{c}\text { Россия, } \\
\text { Томск }\end{array}$ & $\begin{array}{l}\text { 634050, г. Томск, Московский тр-т, 2, } \\
\text { СибГМУ. Кафедра поликлинической } \\
\text { педиатрии с курсом пропедевтики } \\
\text { детских болезней. } \\
\text { Зав. каф. профр. Т.В. Матковская } \\
\text { Тел.: (382-2) 41-06-92, 41-28-01 }\end{array}$ \\
\hline $\begin{array}{c}28 \text { ноября } \\
2003 \text { г. }\end{array}$ & $\begin{array}{l}\text { Областная научно-практическая } \\
\text { конференция «Актуальные пробле- } \\
\text { мы онкологии» }\end{array}$ & $\begin{array}{l}\text { Россия, } \\
\text { Тюмень }\end{array}$ & $\begin{array}{l}\text { Тюменский облонкодиспансер. } \\
\text { М.М. Наумов } \\
\text { Тел.: (345-2) 43-24-23 } \\
\text { Факс: (345-2) 43-44-54 }\end{array}$ \\
\hline $\begin{array}{c}\text { Декабрь } \\
2003 \text { г. }\end{array}$ & $\begin{array}{l}\text { Областная научно-практическая } \\
\text { конференция «Диссеминированные } \\
\text { процессы в легких в практике тера- } \\
\text { певта. Вопросы диагностики и лече- } \\
\text { ния» }\end{array}$ & $\begin{array}{c}\text { Россия, } \\
\text { Томск }\end{array}$ & $\begin{array}{l}\text { 634050, г. Томск, Московский тр-т, 2, } \\
\text { СибГМУ. Кафедра внутренних } \\
\text { болезней педиатрического фракультета. } \\
\text { Зав. каф. профр. Л.И. Волкова } \\
\text { Тел.: (382-2) 41-98-44 } \\
\text { E-mail: luda@mail.tomsknet.ru }\end{array}$ \\
\hline $\begin{array}{c}\text { Декабрь } \\
2003 \text { г. }\end{array}$ & $\begin{array}{l}\text { 9-я Всероссийская научная конфе- } \\
\text { ренция «Энергения, экология, на- } \\
\text { дежность, безопасность» }\end{array}$ & $\begin{array}{c}\text { Россия, } \\
\text { Томск }\end{array}$ & $\begin{array}{l}\text { 634050, г. Томск, Московский тр-т, 2, } \\
\text { СибГМУ. Кафедра поликлинической } \\
\text { педиатрии с курсом пропедевтики } \\
\text { детских болезней. } \\
\text { Зав. каф. проф. Т.В. Матковская } \\
\text { Тел.: (382-2) 41-06-92, 41-28-01 }\end{array}$ \\
\hline $\begin{array}{c}\text { Декабрь } \\
2003 \text { г. }\end{array}$ & $\begin{array}{l}\text { Областная научно-практическая } \\
\text { конференция «Неотложные состоя- } \\
\text { ния в эндокринологии» }\end{array}$ & $\begin{array}{c}\text { Россия, } \\
\text { Томск }\end{array}$ & $\begin{array}{l}\text { 634050, г. Томск, Московский тр-т, 2, } \\
\text { СибГМУ. Кафедра клинической } \\
\text { эндокринологии и диабетологии. } \\
\text { Зав. каф. профр. Е.Б. Кравец. } \\
\text { Доцент кафедры В.А. Столярова } \\
\text { Тел.: (382-2) 53-01-27, 53-12-49 }\end{array}$ \\
\hline
\end{tabular}




\begin{tabular}{|c|l|c|l|}
\hline $\begin{array}{c}\text { Дата } \\
\text { проведе- } \\
\text { ния }\end{array}$ & \multicolumn{1}{|c|}{ Мероприятие } & $\begin{array}{c}\text { Место } \\
\text { проведе- } \\
\text { ния }\end{array}$ & \multicolumn{1}{|c|}{ Контактная информация } \\
\hline $\begin{array}{c}9-10 \\
\text { декабря }\end{array}$ & $\begin{array}{l}\text { Региональная научно-практическая } \\
\text { конференция «География рака в } \\
2003 \text { г. }\end{array}$ & $\begin{array}{l}\text { Рроссия, } \\
\text { Уеля- } \\
\text { Уинском федеральном округе» }\end{array}$ & $\begin{array}{l}\text { Челябинский облонкодиспансер. } \\
\text { В.В. Важенин } \\
\text { Тел.: (351-2) 34-50-14 } \\
\text { Факс: (351-2) 34-49-92 }\end{array}$ \\
\hline
\end{tabular}




\section{II Международная научно-практическая конференция «Медицинские и экологические эффекты ионизирующего излучения»}

\section{Капилевич Л.В.}

20-21 мая 2003 г. в г. Томске состоялась II Международная научно-практическая конференция «Медицинские и экологические эфффекты ионизирующего излучения».

Организаторами конференции являлись Северский биофизический научный центр, Сибирский государственный медицинский университет, Томский научный центр СО РАMН, Центральная медико-санитарная часть ८ 81 , администрация ЗАТО Северск.

Основные проблемы вынесенные для обсуждения:

- проблема оценки воздействия ионизирующего излучения на состояние здоровья человека и объекты окружающей среды;

- проблема обеспечения радиационной безопасности персонала предприятий атомной промышленности;

- проблема радиационно-гигиенического мониторинга.

Сегодня во всем мире расширяется использование атомной энергии в мирных целях. Этот процесс, наряду с позитивным экономическим эффректом, сопровождается нарастанием опасений общественности, экологических организаций, ученых разного профиля. Опасения эти продиктованы имеющимся печальным опытом аварийных ситуаций на объектах атомной индустрии, среди которых главная, несомненно, - авария на Чернобыльской АЭС.

Кроме вопросов безопасного использования атомной энергии, большую актуальность представляет проблема объективной оценки воздействия радиационного фактора на состояние здоровья работников атомной промышленности и их потомков, на состояние здоровья населения, живущего вблизи этих предприятий. Изучение отдаленных эфрфектов воздействия ионизирующего излучения на организм человека представляется сегодня чрезвычайно важной задачей, имеющей не только научное, но и социальное значение.

В этой связи работы в данной области научных знаний заслуживают поощрения и внимания как научной общественности, так и органов государственного управления на всех уровнях. Успешному решению обозначенных проблем способствует открытое объективное обсуждение результатов исследований, проводимых специалистами различных научных направлений.

Конференция «Медицинские и экологические эффректы ионизирующего излучения» продемонстрировала практику открытого обсуждения данной проблемы с привлечением широкого круга ученых и специалистов различного профриля. Единственным требованием, предъявляемым к представляемым материалам, является их достоверность и научно обоснованная аргументация позиции автора.

В работе конференции приняли участие ученые и специалисты различных направленийврачи, биологи, физики, экологи из России, Беларуси, Украины, Казахстана, США, Японии, Великобритании. За 2 дня работы конференции было заслушано 38 докладов. Сборник материалов конференции содержит около 120 работ.

По итогам работы конференции была принята итоговая резолюция, содержащая следующие основные положения:

1. Продолжить практику проведения данной конференции с периодичностью один раз в два года.

2. Считать приоритетными направлениями исследований:

- разработку современной научнообоснованной системы оказания диагностической, лечебной и профилактической помощи лицам, подвергшимся воздействию ионизирующего излучения (персонал радиационно-опасных производств и население, проживающее вблизи их расположения);

— проблему комплексной оценки воздействия ионизирующего излучения на состояние здоровья лиц, подвергающихся воздействию ионизирующего излучения на производстве, и населения, проживающего на территории воздействия объектов атомной промышленности;

- проблему совершенствования системы радиационной безопасности объектов атомной промышленности; 
- проблему эффрективного радиационногигиенического мониторинга предприятий атомной промышленности и объектов окружающей среды.

3. От имени организаторов и участников конференции выйти с предложением в Министерство РФ по атомной энергии, Министерство здравоохранения РФ, Российскую академию медицинских

\section{ОФИЦИАЛЬНАЯ ИНФОРМАЦИЯ}

УКАЗЫ

О проведении в Российской Федерации года инвалидов. Указ Президента РФ от 01.04.2003 г. < 383, г. Москва // ЛФК и массаж. 2003. $<2$.

\section{ПРИКАЗЫ}

Об утверждении форм первичной медицинской документации для психиатрических и наркологических учреждении. Приказ Минздрава РФ от 31.12.2002 г. < 420 // Здравоохранение. 2003. 5 .

О проведении II Всероссийского съезда средних медицинских работников. Приказ Минздрава РФ от 24.01.2003 г. < 15 // Главная медицинская сестра. 2003. « 5.

O применении вспомогательных репродуктивных технологий (ВРТ) в терапии женского и мужского бесплодия. Приказ Минздрава РФ от 26.02.2003 г. < 67, г. Москва // Российская газета. 2003. < 84.

Об отраслевой программе «Скорая медицинская помощь». Приказ Минздрава РФ от 11.03.2003 г. < 93 // Здравоохранение. 2003. « 5.

Отраслевая программа «Охрана и укрепление здоровья здоровых» на 2003-2010 гг. и план мероприятий по ее реализации. Приказ Минздрава РФ от 21.03.2003 г. <114 // Главврач. 2003. 6 . наук о создании государственной федеральной программы по комплексному изучению эффректов воздействия ионизирующего излучения и совершенствованию системы оказания медицинской помощи работникам предприятий атомной промышленности и населению, проживающему на территории их расположения.
Об утверждении Положения об итоговой государственной аттестации выпускников высших учебных заведений РФ. Приказ Минобразования России от 25.03.2003 г. (1155, г. Москва // Российская газета. 2003. < 91.

Об утверждении Положения о порядке проведения государственного контроля эффективности и безопасности лекарственных средств на территории РФ. Приказ Минздрава РФ от 28.05.2003 г. « 223, г. Москва // Российская газета. 2003. < 115.

\section{ПОСТАНОВЛЕНИЯ}

O разработке и финансировании выполнения заданий по обеспечению государственных гарантий оказания гражданам РФ бесплатной медицинской помощи и контроле за их реализацией. Постановление Правительства РФ от 06.05.2003 г. ८ 255, г. Москва // Российская газета. 2003. < 87.

О введении в действие санитарноэпидемиологических правил СП 3.3.2. 1248-03 «Условия транспортирования и хранения медицинских иммунобиологических препаратов». Постановление Главного государственного санитарного врача РФ от 20.03.2003 г. <22, г. Москва // Российская газета. 2003. « 91.

О введении в действие санитарноэпидемиологических правил СП 3.1. 1275-03 «Профрилактика инфекционных заболеваний при эндоскопических манипуляциях». Постановление Главного государственного санитарно- 
го врача РФ от 03.04.2003 г. < 30, г. Москва // Российская газета. 2003. « 91.

О введении В действие санитарноэпидемиологических правил и нормативов СанПиН 2.3.2. 1290-03 «Гигиенические требования к организации производства и оборота биологически активных добавок к пище (БАД)». Постановление Главного государственного санитарного врача РФ от 17.04 .2003 г. < 50, г. Москва // Российская газета. 2003. < 108.

О введении В действие санитарноэпидемиологических правил СП 3.1.2. 1319-03 «Профрилактика гриппа». Постановление Главного государственного санитарного врача РФ от 30.04.2003 г. < 82, г. Москва // Российская газета. 2003. 102.

О введении В действие санитарноэпидемиологических правил СП 3.1.2. 1320-03 «Профилактика коклюшной инфекции». Постановление Главного государственного санитарного врача РФ от 30.04.2003 г. (84, г. Москва // Российская газета. 2003. < 102.

О введении В действие санитарноэпидемиологических правил и нормативов СанПин 1.2. 1318-03 «Порядок выдачи санитарно-эпидемиологического заключения о возможности проведения работ с возбудителями инфекционных заболеваний человека I-IV групп патогенности (опасности), генноинженерно-модифицированными микроорганизмами, ядами биологического происхождения и гельминтами». Постановление Главного государственного санитарного врача РФ от 30.04.2003 г. < 85, г. Москва // Российская газета. 2003. 108.

О введении В действие санитарноэпидемиологических правил СП 3.2. 1317-03 «Профилактика биоза». Постановление Главного государственного санитарного врача РФ от 30.04.2003 г. < 87, г. Москва // Российская газета. 2003. « 100.

\section{ПРОЕКТЫ}

Проект Федерального закона РФ «Об обязательном медицинском страховании в Российской Федерации» // Главврач. 2003. « 5.

Проект Концепции модернизации системы обязательного медицинского страхования в РФ // Приложение к журналу «Главврач». 2003. <4.

Раздел «Научная медицинская информация» подготовлен сотрудниками научномедицинской библиотеки Сибирского государственного медицинского университета: 
М.В. Тереховой, Е.М. Харитоновой, О.В. Коломийцевой, Г.В. Захаровой, С.А. Юдаковой, Г.Н. Сеитовой.

Ждем вашей оперативной и надежной информации о новом в медицине по адpecy:

634050, г. Томск, пр. Ленина, 107.

Тел.: (3822) 51-53-15, 51-57-08.

Факс: (3822) 53-33-09.

E-mail: medlib@tomsk.ru

\section{СИБИРСКИЙ ГОСУДАРСТВЕННЫЙ МЕДИЦИНСКИЙ УНИВЕРСИТЕТ}

в 2003/2004 учебном году открывает новый фракультет -

\section{Клинической психологии и психотерапии}

Специальность- 022700 «Клиническая психология».

Квалификация - клинический психолог, психолог, преподаватель психологии.

Формы обучения - очная - 5 лет (бюджетная и внебюджетная). очно-заочная (вечерняя) - 5,5 года (внебюджетная).

Экзамены - биология, сочинение, математика (по математике принимаются результаты ЕГЭ).

Собеседование - при получении второго высшего образования.

Стоимость обучения (в год) - 35 тыс. руб.

Набор на каждую фрорму обучения - 20 человек.

Постдипломное образование в клинической ординатуре или аспирантуре с дифференцированной

спе-

вания циализацией в области психодиагностики, психологического консультирои специальных методов психотерапии.

Специалисты могут работать:

- в сфере охраны психического здоровья; - в системе образования;

- в психологических службах; - в научных учреждения;

- в реабилитационных центрах; - в сфрере социального обслуживания населения. 